\title{
ECONOMY OF THE THIRD WORLD AND SEARCH FOR GREENER PASTURES IN THE DESERT: FOCUS ON NIGERIA AND HER NEIGHBOURS
}

\author{
Emmanuel Osewe Akubor ${ }^{1}$
}

\section{The Desert before the "Desert": A Historical Definition}

Available historical accounts as documented by scholars, opines that this area presently described as Desert has not always been so, as before now it was an area with beehive of economic activities (KENNY J., 2000). As such, there was a great influx of both human and economics goods in and around the area (KWANASHIE et al., I987). The resultant effect was that by about $700 \mathrm{CE}$ the Kanem Empire began to form in what is now Chad and Libya. This empire was to later absorb other tribes and peoples of northern Nigeria and trade and diplomatic exchange took place in the area.

The majority of the early Hausa states held a strategic geographic location at the southern end of the trans-Saharan route between Tripoli and Lake Chad. This trade route, which originated in prehistoric times and was flourishing in the 8th century, linked the Mediterranean countries to the resources of Sub-Saharan Africa. Trade goods included ivory and slaves (KENNY J., 2000), for example while Ayandele argued that the Yoruba area got good supplies of horses used by the royalties for both warfare and prestige before the $19{ }^{\text {th }}$ century (AYANDELE, E., I979). Usman opined that Kano (nowadays, a Nigerian city) was particularly noted to supply what is today known as Moroccan leather to larger part of North Africa (Morocco and Tripoli), a trade, which only declined after the railway reached Kano in I9I2 (USMAN MOHAMMED, 20I3). The North African traders, primarily Berbers and Arabs, not only brought trade goods, but also the Islamic religion. In Io85, Hummay, a Muslim noble, removed King Selma, the last Duguwa king, from power and established the Sefuwa (also called Sayfawa) dynasty.

I Department of History, Obafemi Awolowo University, Ile-Ife, Nigeria. E-mail: oseweakubor@gmail.com 
The Sefuwa dynasty brought great changes to the Kanem Empire, especially in the area of Islamic culture and civilization.

The import of the above is that this introduction of Islamic culture and civilization led to migration from both sides creating a sort of smooth relationship between the new migrants and their Hausa host (this does not in any way point to the complete absence of conflict, as there were cases of warfare and hostility, but Islam as a religion became a unifying factor) and the fate of the people that were pushed further southwards into the central Nigeria area like the Gwari and others that may have followed them. For those that accepted the dominance of the Sayfawa groups, historians have argued that they were drawn into a network of diplomatic exchanges and relationships, which were made with sultan in North Africa, moreover, during the reign of Mai Dunama Dabbalemi (I22I-I259) especially in the area of pilgrimage and spread of Islam.

Thus from the reign of Mai Dunama Dabbalemi (I22I-I259) down to the present day Nigeria, the area has remained a bee hive of activities especially as it relates to movement of economic goods and services which has continually benefitted the people of both countries. For example, Ayandele (I979) opined that few people realize that in the I8th Century the natron used by the Efik came largely from the Chad Basin; that the Yoruba obtained their horses from Tripoli through Kanuri intermediaries long before the igth century; that, as slaves, a large number of Hausa were an economic asset to the Yoruba. In line with Ayandele's view, Gavin, R and Oyemakinde W, (I989) wrote, that Nigeria acquire rare commodity such as natron or potash cut in slab on the northern edge of Lake Chad. The scholars posited that strings of natron bearing donkeys from the Lake Chad area dotted all the major routes in the north especially from Kano southward to the Niger at Bussa where it met another major rote from Brno along the Benue and thence to Yoruba land or west to Gonja in Ghana. In a more detailed and analytical manner, Watts (I983 cited in Mohammed-Baba, T.A, I989), graphical described the relationship thus:

The northern savanna and the Sahelian biome constituted a human ecological unity in which the affairs of Hausa agriculturalists and semi sedentary Fulani pastoralists were closely integrated with pastoral Wodaabe, Tuareg and other nomadic groups to the north. These partial linkages were embodied in the strong currents of exchange bridging the two regions - the desert culture providing salt, natrons, date and livestock' and the savanna providing the cloth, foodstuff and 
crafts products which conferred a measure of security in the face of climate variation.

The import of the above is that there has been a sort of symbiotic relationship and exchange of goods, services and idea over time across the region, a mark of traditional diplomatic relations and good neighborliness. This is particularly noticeable in the Northern part of Nigeria, where governments of most of the countries around and along the desert areas have continually maintained diplomatic contact. A good example is the case of Libya government uptill the last 20Io's which apart from educational exchange had massively funded the construction of Mosques and other Islamic Centers of worship in Kano and other cities of the North. The government particularly under Gaddafi had embarked on several humanitarian donations and visits to Kano and these other Northern states, most times unannounced, after which he would journey back to his country (KINGSLEY, 2OII).

\section{The Desert and the Young Nigerians: Establishing the Cause}

Scholars have argued that for better understanding of the new relationship existing between the desert and the young Nigerian in post-colonial Africa, we must be able to view it from two angles; viz the romance with the desert caused as a result on lack of better opportunities and the second as caused by wars and conflict (AKUBOR, 20I7). Yaro J. (2008) presented the two situations thus; for the period between the early sixties and early seventies, he wrote:

The deteriorating socio-economic conditions and deepening poverty in the late sixties and early seventies propelled a wide variety of migration configurations. Macro-economic adjustment measures and a huge increase in the number of entrants into the labour market have fuelled a job crisis, creating a sustained pressure for emigration. A significant amount of brain circulation takes place between Ghana, Gambia and Nigeria; Togo and Cote d'lvoire; Burkina Faso, Senegal and Cote d'Ivoire. Since the l970's, highly skilled migrants, including doctors, paramedical personnel, nurses, teachers, lecturers, engineers, scientists and technologists moved from Ghana first to Nigeria and later to other African countries, Europe and North America, attracted by relatively higher salaries and better prospects of living conditions. Many students also remained behind at the end 
of their training as political, economic and social conditions at home deteriorated.

The second stage from the ig8os, according to the scholar witnessed mass movement of human out of Africa, as conditions within the continent became even more unbearable to a larger percentage of the continent's population especially as it relates to war, arms conflict, refugee problems and lack of better opportunity. This in the scholar's opinion adversely affected the development of the continent. The scholar presented his argument thus:

Since the late eighties, traditional labour importing, richer countries in the sub-region (Cote d'Ivoire) and hitherto attractive destinations for migrants (Nigeria) have experienced political and economic crises, which also spur out-migration of their nationals. Until the early l980's, few Nigerian professionals emigrated because domestic working conditions were attractive and internationally competitive. The collapse of oil price, a sharp decline in oil revenue, rapid deterioration in living and working conditions, wage freeze, devalued national currency, declining real incomes, authoritarian military rule and the vacillating economic situation fuelled large-scale emigration of skilled and unskilled workers abroad. Post-apartheid South Africa also attracted highly skilled professionals from Nigeria and Ghana to staff the universities and other sectors and tradesmen from Senegal and Mali including street vendors and small traders from Sierra Leone.

Apart from the above, the economy back home has continued to deteriorate, while the purchasing power of the naira continuously depreciate. Analysts have argued that this is part of the impact of neoliberal policies, which have reduced the value of the national currency of the third world counties (Nigeria inclusive). Some of these includes Nigeria's over dependence on importation without proportional export and industrialization, politics of price of crude oil in the international market and smuggling across the nation's borders (MATHEW, 2006). The result is that pressure is now mounted on the young Nigerians by most parents to travel oversea, where they believe there is dollar rain. This can be better understood when seen in the light of the table below. 
Table 1: Naira to Dollar Exchange Rate History

\begin{tabular}{|c|c|c|c|c|c|c|c|c|c|}
\hline $\begin{array}{l}\text { s/ } \\
\text { no }\end{array}$ & Period & $\begin{array}{l}\text { US } \\
\text { Dollar }\end{array}$ & $\begin{array}{l}\text { Naira } \\
\text { equivalent }\end{array}$ & $\begin{array}{l}\text { Black } \\
\text { Market } \\
\text { Rate }\end{array}$ & s/no & Period & $\begin{array}{l}\text { US } \\
\text { Dollar }\end{array}$ & $\begin{array}{l}\text { Naira } \\
\text { equivalent }\end{array}$ & $\begin{array}{l}\text { Black } \\
\text { Market } \\
\text { Rate }\end{array}$ \\
\hline 1 & 1972 & $\$ 1$ & N0.658 & - & 24 & 1995 & $\$ 1$ & N21.89 & N71.70 \\
\hline 2 & 1973 & $\$ 1$ & N0.658 & - & 25 & 1996 & $\$ 1$ & N21.89 & N84.58 \\
\hline 3 & 1974 & $\$ 1$ & N0.63 & - & 26 & 1997 & $\$ 1$ & $\mathrm{~N} 21.89$ & N84.58 \\
\hline 4 & 1975 & $\$ 1$ & N0.616 & - & 27 & 1998 & $\$ 1$ & N21.89 & N84.70 \\
\hline 5 & 1976 & $\$ 1$ & N0.62 & - & 28 & 1999 & $\$ 1$ & N21.89 & N88-N90 \\
\hline 6 & 1977 & $\$ 1$ & N0.647 & - & 29 & 2000 & $\$ 1$ & N85.98 & N105.00 \\
\hline 7 & 1978 & $\$ 1$ & N0.606 & - & 30 & 2001 & $\$ 1$ & N99-N106 & N104-N122 \\
\hline 8 & 1979 & $\$ 1$ & N0.596 & - & 31 & 2002 & $\$ 1$ & N109-N113 & N122-N140 \\
\hline 9 & 1980 & $\$ 1$ & N0.550 & N0.900 & 32 & 2003 & $\$ 1$ & N114-N127 & N135-N137 \\
\hline 10 & 1981 & $\$ 1$ & N0.61 & - & 33 & 2004 & $\$ 1$ & N127-N130 & N137-N144 \\
\hline 11 & 1982 & $\$ 1$ & N0.673 & - & 34 & 2005 & $\$ 1$ & N132-N136 & - \\
\hline 12 & 1983 & $\$ 1$ & N0.724 & - & 35 & 2006 & $\$ 1$ & N128.50-N131.80 & - \\
\hline 13 & 1984 & $\$ 1$ & N0.765 & - & 36 & 2007 & $\$ 1$ & N120-N125 & - \\
\hline 14 & 1985 & $\$ 1$ & N0.894 & N1.70 & 37 & 2008 & $\$ 1$ & N115.50-N120 & - \\
\hline 15 & 1986 & $\$ 1$ & N2.02 & N3.90 & 38 & 2009 & $\$ 1$ & N145-N171 & - \\
\hline 16 & 1987 & $\$ 1$ & N4.02 & N5.90 & 39 & 2010 & $\$ 1$ & N148.21-N154.8 & - \\
\hline 17 & 1988 & $\$ 1$ & N4.54 & N6.70 & 40 & 2011 & $\$ 1$ & N151.05-N165.1 & - \\
\hline 18 & 1989 & $\$ 1$ & N7.39 & N10.70 & 41 & 2012 & $\$ 1$ & N155.09-N161.5 & - \\
\hline 19 & 1990 & $\$ 1$ & N7.39 & N10.70 & 42 & 2013 & $\$ 1$ & N153.21-N162.9 & - \\
\hline 20 & 1991 & $\$ 1$ & N8.04 & N9.30 & 43 & 2014 & $\$ 1$ & N170-N199 & - \\
\hline 21 & 1992 & $\$ 1$ & N9.91 & - & 44 & 2015 & $\$ 1$ & N199-N300 & - \\
\hline 22 & 1993 & $\$ 1$ & N17.30 & N21.90 & 45 & 2016 & $\$ 1$ & N300-N320 & N310-N370 \\
\hline 23 & 1994 & $\$ 1$ & N22.33 & N56.80 & 46 & 2017 & $\$ 1$ & N360 & - \\
\hline
\end{tabular}

Source: MATHEW, Womack Ryan “The Emergence of Neoliberalism and Free Trade in the Developing World" (2006), University of Tennessee Honors Thesis Projects. https://trace.tennessee.edu/utk_chanhonopio/ıozo

\section{Unemployment, Frustration and the Young Nigerians}

In his analysis of the unemployment situation in Nigeria, Nasir El Rufai (20I0), posited that at present, Nigeria has about 90 million people who are willing and able to work, but about 70 million of them have no gainful 
employment. But when the 4.7 million people captured in the formal sector in the latest statistics from the Pensions Commission is increased by the 3 to 4 times standard multiplier to capture those in the informal sector, it means that only about 20 million Nigerians have jobs, out of a population of I 62 million. This simple fact causes the country a loss of about $\mathrm{N} 2$ trillion annually from the absence of commercial activities that ordinarily should have taken place but did not. He argued further thus:

The most despairing aspect is the fact that the worst affected are Nigerians between the ages of $2 \mathrm{I}$ and 40 years - the future leaders of our country. In 1963 , our population was about 56 million, a large percentage of which was employed. The employment to population ratio grew until the early I980s when it started to decline. Officially, the unemployment rate is I9.7 percent. This means that at least I8 million Nigerians have no jobs and cannot meet their responsibilities. The effects of unemployment on the person and the country can be catastrophic. At current rates, even if government policies, enabling environment and direct efforts manage to create I million new jobs a year, it would take 18 years to close the existing job gap. Except that by that time, at least 54 million more Nigerians would have joined the workforce....As at I996, 2.8 million job seekers entered the Nigerian labour market annually, but only about io percent of them found employment. Perhaps, today's figures are too scary for government to release, but unemployment is too critical for government to play political ostrich with. The average years of studies and Return on Investment (ROI) for a university degree in Nigeria are both 5 years, yet it takes an average Nigerian graduate an average of another five years to find what can be considered a stable job. Many others, especially those without 'godfathers' remain for longer periods without jobs no matter how qualified they may be. Not only are large numbers of Nigerian graduates unemployed or underemployed; many are unable to apply the skills learnt in school. There are also large segments of the employed population who are simply wasting away, doing things they really have no business doing - just to remain alive.

The above position is made clearer by the statistics released by Akinyosoye, Vincent (2OII) and National Bureau of Statistics, in which it argued that unemployment rates in 16 states, including the Federal Capital Territory, are higher than the $19.7 \%$ national average. The analysis indicated that Bayelsa State has the highest composite unemployment rate of $38.4 \%$, followed by Katsina State, whose rate stands at $37.3 \%$. Other states with higher-than-average unemployment rates, according to the survey, are Bauchi State (37.2\%), Akwa Ibom State (34.I\%), Gombe State (32.I\%), Adamawa State (29.4\%), Rivers State $(27.9 \%)$, Borno State (27.7\%) and Kano State (27.6\%). Yobe, Taraba, Jigawa, 
Sokoto, Imo and Ekiti states' unemployment rates stood at $27.3 \%, 26.8 \%$, $26.5 \%, 24.4 \%, 20.8 \%$ and $20.6 \%$, respectively.

At the end of 2016 , it was reported that the young Nigerians are fast becoming frustrated. Specifically, Peter Osalor (20I6) noted thus:

On Employment, 4.58 million Nigerians have become jobless since last year (20I5), adding 2.6 million to unemployment figures of 1.46 million recorded in the third quarter of 2015 and 518.IO2 in the fourth quarter of 20I5. According to reports during the reference period, the unemployed in the labour force increased by I,I 8,700 persons, resulting in an increase in the national unemployment rate to $\mathrm{I} 3.3 \%$ in Q2 2016 from I2.I in 20I6, $10.4 \%$ in 2015 from $9.9 \%$ in Q3 2015 and from $8.2 \%$ in Q2 2015 .

On labour productivity, it continued thus:

...Q2 showed that investment in the economy was low in terms of volume of private investment and Foreign Direct Investment (FDI), compared to the previous year. The unemployment rate rose by I $2.2 \%$ over the previous quarter and slowed productivity as recorded by GDP, NBS reported. As should be expected with the development, job creation both private and public sector recorded negative figure of $-4,288$ for the fourth quarter of 2015 and has continued up till the Q2 of 20I6. Nigeria Gross Domestic Product (GDP) report of Q2 2016 showed decline by $-2.06 \%$ (year-on-year) in real terms. This was lower by $1.70 \%$ point from growth rate of $-0.36 \%$ recorded in the preceding quarter.

The NBS report also showed that Nigeria Capital Importation for Q2 2016 has a total volume of capital imported into the country to be \$647.I million, which represented a fall of $8.98 \%$ relative to the QI and a fall of $75.73 \%$ relative to $\mathrm{Q} 2,2015$. The report also revealed that unemployment in Q2 stood at $13.3 \%$, underemployment $19.3 \%$ and youth unemployment 49.5\%. This means that a country of about I70 million with youth population put at half of this number, unemployment is really a time bomb.

The situation did not in any way show sign of improvement as at the end of 20I7, remaining gloomy and the people getting even more frustrated. This is clear from the statistics as reeled out by the National Bureau of Statistics which pointed out that between January and September 20I7, a total number of 4.07 million Nigerians became unemployed. According to the bureau, the number of Nigerians that became unemployed rose from II.92 million in the first quarter of 2017 to 13.58 million and I5.99 million 
in the second and third quarters respectively. It also reported that between the second quarter and third quarter, the number of economically active or working age population ( $\mathrm{I5}-64$ years of age) increased from IIO.3 million to III.I million. The NBS report said the increasing unemployment and underemployment rates imply that although Nigeria's economy is officially out of recession, domestic labor market is still fragile and economic growths in the past two quarters in 2017 have not been strong enough to provide employment in Nigeria's domestic labor market.

It reads in part,

The labor force population increased from 83.9 million in Q2 2017 to 85.I million in Q3 20I7. The total number of people in full-time employment (at least 40 hours a week) declined from 52.7 million in Q2 20I7 to 5I.I million in Q3 20I7. The unemployment rate increased from I4.2 percent in Q4 2016 to I6.2 percent in Q2 2017 and I8.8 percent in $\mathrm{Q}_{3}$ 20I7. The number of people within the labor force who are unemployed or underemployed increased from 13.6 million and I7.7 million respectively in Q2 20I7, to I5.9 million and I8.0 million in $\mathrm{Q}_{3}$ 20I7. Total unemployment and underemployment combined increased from 37.2 per cent in the previous quarter to 40 per cent in $Q_{3}$ 20I7.[...] During the third quarter of this year, 2I.2 percent of women within the labor force that were between the ages of 15 years and 64 years and willing, able, and actively seeking work were unemployed, compared with $\mathrm{I} 6.5$ percent of men within the same period.

Furthermore, the NBS noted in the report that in the third quarter of 20I8, I6.4 percent of rural and 23.4 percent of urban dwellers within the labor force were unemployed. It added that the rate of unemployment is increasing at a slightly faster rate for dwellers than it was for their rural counterparts.

The tables below gives a graphics picture of the sordid situation.

\section{Table II: National Unemployment Rates (2000-2009)}

\begin{tabular}{|l|l|l|l|}
\hline Year & Rates & Year & Rates \\
\hline 2000 & 13.1 & 2005 & 11.9 \\
\hline 2001 & 13.6 & 2006 & 12.3 \\
\hline 2002 & 12.6 & 2007 & 12.7 \\
\hline 2003 & 14.8 & 2008 & 14.9 \\
\hline 2004 & 13.4 & 2009 & 19.7 \\
\hline
\end{tabular}


Source: http://punchng.com/four-million-nigerians-became-jobless-this-year-nbs/

Table III: Unemployment Rates in Nigeria by State, March 2009

\begin{tabular}{|c|c|c|c|c|c|c|c|c|}
\hline$S / N$ & State & $\begin{array}{l}\% \\
\text { Unemploy- } \\
\text { ment } \\
\text { lin declining } \\
\text { orderl }\end{array}$ & $S / N$ & State & $\begin{array}{l}\% \\
\text { Unemploy- } \\
\text { ment } \\
\text { (in declining } \\
\text { order) }\end{array}$ & $S / N$ & State & $\begin{array}{l}\% \\
\text { Unemploy- } \\
\text { ment } \\
\text { lin declining } \\
\text { order) }\end{array}$ \\
\hline 1 & Bayelsa & 38.4 & 13 & Sokoto & 22.4 & 26 & Zamfara & 13.3 \\
\hline 2 & $\begin{array}{l}\text { Katsina } \\
\text { State, }\end{array}$ & 37.3 & 14 & FCT & 21.5 & 27 & Osun & 12.6 \\
\hline 3 & Bauchi & 37.2 & 15 & Imo & 20.8 & 28 & Edo & 12.2 \\
\hline 4 & $\begin{array}{l}\text { Akwa } \\
\text { Ibom } \\
\text { State }\end{array}$ & 34.1 & 16 & Ekiti & 20.6 & 29 & Ebonyi & 12.0 \\
\hline 5 & $\begin{array}{l}\text { Gombe } \\
\text { State }\end{array}$ & 32.1 & 17 & Lagos & 19.5 & 30 & Kebbi & 12.0 \\
\hline 6 & $\begin{array}{l}\text { Adamawa } \\
\text { State }\end{array}$ & 29.4 & 18 & Kogi & 19.0 & 31 & Niger & 11.93 \\
\hline 7 & Rivers & 27.9 & 19 & Delta & 18.4 & 32 & Kaduna & 11.6 \\
\hline 8 & Borno & 27.7 & 20 & Anambra & 16.8 & 33 & Kwara & 11.0 \\
\hline 9 & Kano & 27.6 & 21 & Enugu & 14.9 & 34 & $\begin{array}{l}\text { Nassa- } \\
\text { rawa }\end{array}$ & 10.1 \\
\hline 10 & Yobe & 27.3 & 22 & Ondo & 14.9 & 35 & Benue & 8.5 \\
\hline 11 & Taraba & 26.8 & 23 & Оyо & 14.9 & 36 & Ogun & 8.5 \\
\hline \multirow[t]{2}{*}{12} & Jigawa & 26.5 & 24 & Abia & 14.5 & 37 & Plateau & 7.1 \\
\hline & & & 25 & $\begin{array}{l}\text { Cross- } \\
\text {-River }\end{array}$ & 14.3 & & & \\
\hline
\end{tabular}

Source: Akubor, E. Osewe (20I7), Attaining Millennium Development Goals in the Midst of Corruption in Nigeria: Reality or Fiction? Ibadan Dominican Studies, Vol. 3, Dominican Institute Ibadan, January 20I7, Pp. I75-200

From the above statistics, it should be clear that it will take patriotism on the part of those affected to remain in the country. Thus, it was therefore not surprising to observers that Nigerian women and girls were from the later 
I990's taken to Europe, especially to Italy and Russia, and to the Middle East and North Africa, for forced prostitution. Due to desperation on the part of the victims and the quest to make money by the Traffickers, the victims were moved to Europe by caravan, forcing them to cross the desert on foot, and subjecting them to forced prostitution to repay heavy debts for travel expenses. During the reporting period, Nigerian girls were repatriated from Libya and Morocco, where they were reportedly held captive in the commercial sex trade. In 20I0, Hon. Mathew Egbadon, then speaker of the Edo state House of Assembly made it public that he got a letter from the Nigerian ambassador to Italy stating that out of about Io,000 prostitutes in that country, 80 percent of them were from Edo State (NIGERIA, 20IO).

\section{The Desert Economy and Encouraging Factor: The Libyan Example}

Apart from the fact that historically a sort of traditional trade route had existed from the northern part of the country through Agadez to Libya, the young frustrated Nigerians are often encouraged by the fact that the situation in Libya as well as Libyan economy offers far encouraging situation than what is obtainable in Nigeria, and is such that they could cope with while waiting to cross to Europe. As such, the first camp while on transit is Libya. To some others, of all routes, it is the cheapest ${ }^{2}$. While the Nigerian economy seems to be experiencing downwards trend, the desert as exemplified by Libya from 1977 onward, per capita income in the country rose to more than US\$ II, ০০o, the fifth-highest in Africa ${ }^{3}$. The Human Development Index became the highest in Africa and greater than that of Saudi Arabia. This was achieved without borrowing any foreign loans, keeping Libya debtfree (AZAD, 20II). In addition, the country's literacy rate rose from Io\% to $90 \%$, life expectancy rose from 57 to 77 years, employment opportunities were established for migrant workers, and welfare systems were introduced that allowed access to free education, free healthcare, and financial assistance for housing. The Great Manmade River was also built to allow free access to fresh water across large parts of the country (ZIMBABWE, 20II). In addition,

2 This information was obtained from one of my informant who made the journey through the desert on three occasions. He is Moses Iyoha, a Nigerian, from Edo state. Interview was conducted at Igueben village, Edo state, Nigeria, 22/6/20I4.

3 African Countries by GDP Per Capita > GDP Per Capita (most recent) by Country". NationMaster. Retrieved 24 July $201 \mathrm{I}$ 
financial support was provided for university scholarships and employment programs (SHIMATSU, 20II).

The country under the leadership of Gaddafi doubled the minimum wage, introduced statutory price controls, and implemented compulsory rent reductions of between 30 and $40 \%$. Gaddafi also wanted to combat the strict social restrictions that had been imposed on women by the previous regime, establishing the Revolutionary Women's Formation to encourage reform. In I970, a law was introduced affirming equality of the sexes and insisting on wage parity. In I97I, Gaddafi sponsored the creation of a Libyan General Women's Federation. In I972, a law was passed criminalizing the marriage of any females under the age of sixteen and ensuring that a woman's consent was a necessary prerequisite for a marriage (BEARMAN, I986).

Generally, a summary survey of the government of government welfare program shows that uptill the late 2000's, it was channeled for the welfare of the people. This is how some analysts have accessed the case of Libya vis a vis Nigeria:

- A portion of Libyan oil sale is, credited directly to the bank accounts of all Libyan citizens

- There was no interest on loans, banks in Libya are state-owned and loans given to all its citizens at ०\% interest by law

- There was no electricity bill in Libya; electricity was free for all its citizens

- Education and medical treatments are free in Libya. Before Gaddafi, only $25 \%$ of Libyans were literate. Today the figure is $83 \%$

- Should Libyans want to take up farming career, they would receive farm land, a farm house, equipments, seeds and livestock to kick-start their farms - all for free

- If Libyans cannot find the education or medical facilities they need in Libya, the government fund them to go abroad for it not only free but they get US\$2,300/MTh accommodation and car allowance

- In Libyan, if a Libyan buys a car, the government subsidizes $50 \%$ of the price

- The price of petrol in Libya is \$o.I4 (N22) per litre

- Libya has no external debt and its reserves amount to \$150 billion - now frozen globally 
- If a Libyan were unable to get employment after graduation, the state would pay the average salary of the profession as if he or she is employed until employment is found.

- Late Gaddafi carried out the world's largest irrigation project, known as the Great Man-Made River project, to make water readily available throughout the desert country (OSEWE, 2OI2).

\section{Adventure or the Route of the Valley of the Shadow of Death: Interrogating the Course}

Generally it has been established unemployment and poverty in Nigeria has led to a situation in which young Nigerians and their counterparts from other African countries see Europe as heaven, and the desert through Libya as the Gateway and as such those in this categories who are mostly youth are ready to do anything to get to get out of Africa. For example, in the third quarter of 2014 there was an estimated I28,725 illegal immigrants on its territory. Most of these end up as asylum seekers. According to available statistics, the number of asylum seekers could surge to $700,000(+28 \%)$; this is just as the number of illegal entries into Europe could rise beyond the 276, II 3 in $2014(60,000 \text { of whom via the sea })^{4}$. The detected flow of illegal immigrants has never been as high as in 20I4, up by I70\% in comparison with 2013. It is due to surge again in 2015 in which the first two months recorded an increase of over $200 \%$ in comparison with 2014 . According to statistics, since I 988 nearly 20,000 people have died on the external borders of the European Union. In 20I4, the number of victims rose beyond 3,500. Statistics also shows that $90 \%$ of illegal migrants have taken the maritime route across the Mediterranean. Identified illegal immigration has grown eight-fold in Italy, it has doubled in Greece and has upped by $50 \%$ on the Spanish borders. In 20II, which was already an exceptional year, the migratory phenomenon found its explanation mainly in the economic situation in certain countries bordering the Southern Europe shores 5 .

Scholars have identified three major route through which Nigerians and other young Africans in general leave the continent through the desert.

\footnotetext{
4 This is contained in the document of Pan Africa Initiative Against Irregular And Dangerous Migration (PAIIDAM), an Initiative of Senator Shehu Sani presented to the Nigerian Immigration Service. Abuja, Nigeria, 2016

5 Ibid
} 
The first notable and notorious route is the central Mediterranean link associated with Libya, Italy, Malta and Tunisia. These according to research have since 2013 become the main path by which illegal immigrants set off towards Europe. The notoriety of this route is seen in the figures mainly from Italy, which are spiraling. According to this, the number of castaways rescued in 2014 rose to over I70,000, 30,000 of whom were aided by coast guards as well as merchant ships and 70,000 by the Mare Nostrum operation, launched by the Italian government on I8th October 2013 after the drama of Lampedusa. The number of illegal border crossings observed totaled 134, 272 between January and September 20I4, in other words six times the 2013 figure and twice that during the Arab Spring. Migrants still come from Sahel, mainly from Libya (90\%), now a transit country, and also from Syria via Egypt (5\%) where the refugee situation is precarious.

The second and well-known route is the Morocco, Senegal, and Sahara. From this point, most migrants target Portugal and Spain. It remains however that there has been a further rise in immigration bids via the sea $(6,13 \mathrm{I}$ interceptions between January and September 20I4), since the narrow Gibraltar Strait makes it easy to use boats of any size. "Group" crossing on borders of the Spanish enclaves of Ceuta and Melilla in Morocco are increasingly spectacular.

It is on record that the number of wreckages leading to losses of life is on the increase, for example it is on record that in 2014 alone there were number of shipwrecks carrying illegal immigrants and the actives of patrol team led to the rescue of over 40,000 during this period. In 2014 in the Mediterranean, there were over 15,000 rescue operations at sea ${ }^{6}$.

Specifically during this period, The Nigerian area in particular and the West African territory in general fast became notorious from irregular and dangerous migration especially among her youths. Available data on the volume of migrants making use of the western and central routes are derived from Agadez trail running from the Nigerien city to Algeria. Statistics shows that more than 5,000 West Africans left Agadez to travel to North Africa each month between March and August 2013. In addition, it is estimated that half of all West African migrants who arrived in Lampedusa in 2013 passed through Agadez. It has also been established that the cost of migration along this routes vary depending on the point of departure and destination. The journey from Agadez to the Libyan Coastline cost between USD 2000-3000. The Global Initiative against Transnational Organized Crime states that the "full packet solution" through this route cost USD I०,০००

6 Ibid 
or more and is often payable in various installments by the families of the migrants when they have proof that their loved ones have reached a specific destination. Also study found that the route from Agadez to Sabha in Libya cost approximately USD Iо०-300 and the more dangerous desert crossing from Agadez to Tamanrasset in Algeria cost between USD 50-300. Within Libya in 2OII, it was reported that migrants paid around USD 800 to be taken from southern town of Sabha to northern Tripoli.

The third is associated with Greece, Cyprus, Bulgaria, Romania, which presently serves as the most important routes (this is not directly relevant to our discourse, but it is worth mentioning as it has also become route through which frustrated young Nigerians and their colleagues from other neighbouring African states, escape harsh economic conditions). It is on record that until 2012, this constituted the main illegal immigration route counting for nearly half of migrants. It is estimated that since 2000 nearly 3 million immigrants have entered Europe illegally via Greece.

\section{From Freedom to Slavery: Examining the Cartel and the Cost}

From the point of history, it is important to note that the sale and use of Black Africans as slaves in the desert is not new as has been pointed out at the opening part of the paper. Even though the slave trade was officially abolished in Tripoli in I853, in practice it continued until the I89os and even beyond (MCLACHLAN, I978). The Tuareg and others who are indigenous to Libya facilitated, taxed and partly organized the trade from the south along the trans-Saharan trade routes. In the I830's - a period of time when slave trade flourished - Ghadames was handling 2500 slaves a year. Black slaves have also been part of the trade article from time and, therefore, part of the reason Abdullahi Danfodio, the brother of the $19^{\text {th }}$ Century Fulani Jihadist had to abandon the course. Hodgkin particularly noted that Abdullahi was disappointed in his brothers constant capture of black slave which he traded to North Africans even though he claimed his course was for the liberation of the people (HODGKINS, I960). Then, while the people travelled with the intention of seeking greener pastures, a large chunk of their hosts were already waiting to take them how slaves for domestic works (house chores) farm work and digger7. It has been established that apart from the direct sale

7 CNN Exclusive Report: People for Sale: Where lives are auctioned for \$400. Cnn. com/20I7/II/I4/Africa/Libya-migrants-auctions/index.html 
of Nigerians by Libyans, a cartel of Nigerians are also involved in the sale of Nigerians (DAYO et al., 20I7). The cabal includes family members, friends and contacts who most often are well known to the victims and promise to facilitate their movement from Nigeria to Europe through the Desert. Apart from the direct sale of Nigerians, some militants are involved. Ofehe S. (2OI7) put it thus:

It is important to note the presently there is no government in Libya, you only have ISIS, Al Qaeda and militias using Nigerians and other people to raise money to fund their terrorist activities; as such, they sell these Nigerians as slaves to raise money or use them as direct labour and collect the money that is supposed to be paid to them. This forms the proceeds to purchase arms, feed themselves and army as well as move around.

From the above, it can be argued that apart from the money they bring in to their captures, they were also used for purposes of the larger Jihadist movement in the area as well as instrument for the destabilization of the area in particular and the entire region in general. This has been well attested to by some of the returnees who said that apart from using them to carry dead bodies, they also carried bombs and guns for militant groups in the area ${ }^{8}$.

Oketola Dayo, et al., argued that some of these Nigerians were sold for 3000 dinars (about N794, 000) at Agadez in Niger and Sabha in Libya. In other instance the Nigerians slave dealers sold women for 5,000 Dinar and Men for 4,000 Dinars. The situation becomes even more pathetic when it is clear that these people paid to be enslaved. For instance, available record shows that some of them paid between N600,000 and N800,000 to cross over to Italy but were left stranded in Libya.

Generally, in term of the physical human loss, it is estimated that between 65,000 and I20,000 sub-Saharan Africans enter the Maghreb (Mauritania, Morocco, Tunisia, Algeria, and Libya) yearly, of which 70 to 80 percent are believed to migrate through Libya and 20 to 30 percent through Algeria and Morocco. Several tens of thousands of sub-Saharan Africans try to cross the Mediterranean each year (ADEPOJU, 2005). Since the journey is not made in the day or two, these human beings are cramped together in conditions ordinarily not fit for human existence. According to various estimates, at least I0०,000 sub-Saharan migrants now live in both Mauritania and Algeria, I to I.5 million in Libya, and anywhere between 2.2 and 4 million mainly Sudanese in Egypt. Tunisia and Morocco house smaller but

8 Connectwarri.com.ng/20I7/ı2/they-used-us-to-carry-bombs-libya-is.html?m 
growing sub-Saharan immigrant communities of several tens of thousands (ADEPOJU, 2005). This is considered great social and particularly economic loss to the home country, because although many of these migrants are commonly portrayed as "destitute" or "desperate", it has however been established that majority of the migrants are often relatively well educated and from moderate socio-economic backgrounds. They move because of a general lack of opportunities, fear of persecution and violence, or a combination of both (ADEPOJU, 2005).

In term of the direct economic cost and loss to Nigeria, scholars have argued that since the trade is illegally conducted it is difficult to get the actual figure involved. Jorgen Carling (cited in Asenime, 20I2), reported that as early there were about Io,००० Nigerian women in prostitution in Italy and they were illegally taken out through the desert with the promise of better employment by family and friends on arrival (JOGAN, 2005). Asenime J. (20I2), opined that by the second quarter of 2008 , there were about 20,000 Nigerian girls engaged in commercial sex in Italy, including 3000 in Turin alone. It has also been established that earlier in 1999 about 500 had been deported back to Nigeria from Italy. Most of these Nigerians made it to Italy via Libya through the Desert (UNESCO, 2006).

Available records shows that Nigerians top the charts of arrivals in Italy by sea in 20I7. This is explained in the table below (ELBAGIR et al., 2018).

\begin{tabular}{|l|l|l|l|}
\hline s/no & Country & Figure & Position \\
\hline 1 & Nigeria & 37,551 & First \\
\hline 2 & Eritrea & 20,718 & Second \\
\hline 3 & Guinea & 13,342 & Third \\
\hline 4 & Cote d'Ivoire & 12,396 & Fourth \\
\hline 5 & Gambia & 11,929 & Fifth \\
\hline
\end{tabular}

Source: CNN Exclusive Report: Don't Struggle if you're Raped; http:www.cnn. com/2018/02/27/Africa/Nigeria-migrant-smugglers.intl/index.html

Similarly, it has been established that a large number of these were female Nigerians and the since 2012 that figure has continued to rise. The table below gives a clearer picture of this trend and the figures involve (ELBAGIR et al., 20I8). 


\begin{tabular}{|l|l|l|l|}
\hline s/no & Year & Figure & Means of arrivals \\
\hline 1 & 2012 & 87 & Sea \\
\hline 2 & 2013 & 433 & Sea \\
\hline 3 & 2014 & 1,454 & Sea \\
\hline 4 & 2015 & 5,633 & Sea \\
\hline 5 & 2016 & 11,009 & Sea \\
\hline
\end{tabular}

Source: CNN Exclusive Report: Don't Struggle if you're Raped; http:www.cnn. com/2018/02/27/Africa/Nigeria-migrant-smugglers.intl/index.html

Adepagba et al. pointed out that in 2017 no fewer than Io, ००० Nigerians died between January and May died while trying to illegally migrate through the Mediterranean Sea and the Desert. The document also reported that Deputy Head of EU Delegation to Nigeria, Mr. Richard Young opined that in 20I4 the number of people travelling illegally through the desert was 280,000; in 2015, it rose to I.8 million while in 2016 between January and September it was 420,000 that were involved in this act (ADELANI, 20I7). On the other hand, it was widely reported that twenty seven thousand Nigerians seeking pastures abroad died in their in their quest to reach Europe through the desert and sea in 2016 according to non-government organization RARDUJA International (ADEBUMITI, 20I7). Similarly, the President of Pan African Institute for Global Affairs and Strategy reported that 7000 Nigerians vanished in desert in 2016 . According to this report, $68 \%$ of the figure were graduates who were looking for greener pasture in the foreign land, yet they ended up as sex slaves and ready tools for all forms of social vices (ABUBAKAR, 20I7).

From the above it is clear that while it is difficult to arrive at specific figure of what has been lost in economic term in the desert as result of frustration among young Nigerians, we cannot however deny the fact that it is alarming.

Yaro J. (2008) gave a general picture of the economic loss of migration to the country in particular and the region in general thus:

Since the late eighties, traditional labour importing, richer countries in the sub-region (Côted'Ivoire) and hitherto attractive destinations for migrants (Nigeria) have experienced political and economic crises, which also spur out-migration of their nationals. Until the early I980's, few Nigerian professionals emigrated because domestic working conditions were attractive and internationally competitive. The collapse of oil price, a sharp decline in oil revenue, rapid deterioration in living and 
working conditions, wage freeze, devalued national currency, declining real incomes, authoritarian military rule and the vacillating economic situation fuelled large-scale emigration of skilled and unskilled workers abroad. Post-apartheid South Africa also attracted highly skilled professionals from Nigeria and Ghana to staff the universities and other sectors and tradesmen from Senegal and Mali including street vendors and small traders from Sierra Leone.

On the rural economy, the Scholar opined:

The process of rural-urban or rural-rural migration has created "Empty Spaces" in the rural economy. By empty spaces is meant the labour vacuum created by the absence of the many rural out migrants. The impact of these spaces in the rural economy cannot be overstated, especially with regards to disruption of rural livelihoods. Out migration leads to drastically reduced labour size and quality, which in turn reduces farm size and quality of work resulting in reduced food production and reduced household wealth with consequences of increased vulnerability in many rural areas leading to food insecurity.

On its part The Pan Africa Initiative against Irregular and Dangerous Migration (PAIIDAM, 20I6) noted thus:

...Presently, the supply of skilled people in our area can be said to be inadequate due to a number of constraints that hinder human resources development and capacity building. In the case of Nigeria, the primary cause of external brain drain is the unreasonably low wages paid to professionals. The contradiction is that we spend four billion dollars annually to recruit and pay 100,000 expatriates to work in different parts of the country but fail to spend a proportional amount to recruit the 250,000 Nigerian and other African professionals now working outside the continent. ...On a daily basis desperate applicants besiege the embassies of economically prosperous countries where they believe they could get better economic deals. For instance, between January 2015 and March 20I6, the UK mission in Nigeria recorded that it issued visas to I4,23I Nigerians, making them one of the top Io nationalities granted visas in the world.

Statistics shows that the numbers of Nigerians leaving the country has been steadily increasing year by year. In 2010, 64,279 Nigerians were issued visas by the US mission in Nigeria, but the number dropped to 63,503 in 20II. In 20I2, the figure increased to 83,944 and to II3,503 in 2013 and to I4I,527 in 20I4. It was gathered that 42 Nigerians were granted special immigrant visas out of the II6 issued to Africans last year. 
The import of this is that the country is generally been deserted by skilled manpower from needed for the development of the country. These were trained with scarce resources and desperately needed for the management of the development process.

\section{Returning to the Land: Any Hope?}

Since the beginning of 20I7, the International Organisation for Migration facilitated repatriation brought back 5,578 Nigerian migrants who were trapped in and outside prisons across Libya - mostly of Edo-Delta origin. In November alone, the International Organisation for Migration with the backing of the European Union retrieved I,295 stranded Nigerians from Libya (DAYO et al., 20I7).

According to African Union Commission, as at the end of 2017 over 400,000 Nigerians were stranded in Libya. Specifically it was noted that the figure was between 400,000 and 700,000, while about 3,800 migrants languish in camp near Tripoli (DAYO et al., 20I7). Although the Nigeria government have made several attempt to lure back these brains to the country, there is however no indication that there is any hope in term of economic engagement and upliftment for them in the country. Unfortunately, since independence successive governments in Nigeria have continued to encourage this mass migration, through policies and acts that does not provide the conducive environment for the best brains to remain and develop the country.

As it is today, in many developed economies, highly qualified labour - for knowledge-intensive activities - is being recruited from poor and emerging market economy countries with specific focus on Nigeria. Presently, Nigerians and Zambians, highly skilled professionals constitute about a half or more of expatriates living in OECD countries. This is indeed a danger sign for the African continent especially in this age of globalization (ADEPOJU, 2005) 9 .

9 Adepoju Aderanti, 2007, Highly Skill Migration: ... Op.cit: p.33 


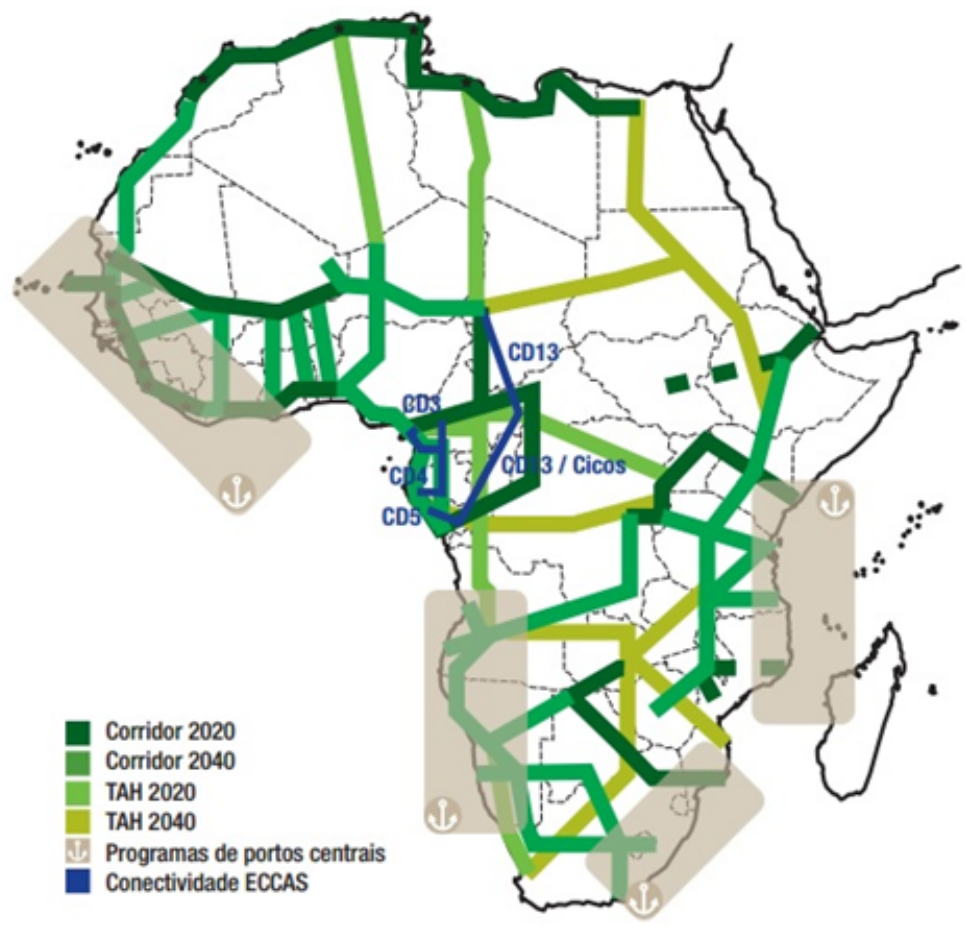

\section{Conclusions}

From the above it is clear that Nigeria is far from any form of technological advancement and development. This as have been explained is tied to mass migration in search for greener pasture in the desert, which denied the country of her best, while helping to develop the European world.

From the discourse so far, it is clear that the only way to stop this brain drain and mass migration is Entrepreneurial revolution that will keep the youths purposefully engaged and economically uplifted. With about $70 \%$ youth population (Approximately 80 million), there is an abundance of human resources, which can transform any economy positively. There is the need for the state and individuals create jobs for the growing population of youths. The state must also put in place incentives well as create the right environment for skill and entrepreneurial development. However, there are numerous challenges hindering the growth of entrepreneurship in Nigeria, they are: lack of access to fund; over taxation of small and medium scale 
Enterprises; insufficient power to maintain the industries; lack of critical infrastructures; insecurity. All these must be put in place to be able to check this menace.

\section{References}

Abbakar S., "Aspect of an Urban Phenomenon: Sokoto and its Hinterland to C. 1850 " in

Y.B Usman (ed.) The Sokoto Caliphate, Lagos, A.B.U., pp. I25-I39. I979

Abubakar, Auwal. Illegal Migration: 7000 Nigerians Vanished in Desert in 20I6, Daily Trust; https//www.dailytrust,com. August. 2017

Abubakar, B. 2008, the Perception of Archaeology in Africa: Opportunities and Potential, IJNA 37.2, 387-388.

Adebumiti, Adelowo (20I7); 27,000 Nigerian Migrants died last year. Guardian, http///guardian.ng/27000-nigerian

Adelani, Adepegba et al. Illegal migration: Io, ০০০ Nigerians die in Mediterranean Sea, Desert-NIS, Punch, May 20. 2017

Adeleye R.A, "Hausaland and Borno I600-I800" in Ajayi and Crowder (eds.) History of West Africa, Vol. I 2nd ed. London, Longman. pp. 556-601. 1976

Adepoju, Aderanti (2007), Highly skilled migration: balancing interests and responsibilities and tackling brain drain, Global Forum on Migration and Development, Belgium; United Nations Expert Group Meeting on International Migration and Development, Population Division, Department of Economic and Social Affairs, United Nations Secretariat, New York, 6-8 July 2005

Akubor. Emmanuel Osewe, Nigeria's Valley of Death: Historicizing Environmental Degradation in the Niger Delta and its Impact on Human Development, in Akpotor, S.A, et al. Five Decades of Petroleum Production in Nigeria: Impact on the Niger Delta. Delta State University, Abraka, Delta State Pp I63-I80. 20I2

. Climate Change, Migration and Conflict: A Historical Survey of People of Northern Nigeria and their Neigbhours from the period of the Mega Chad. The Humanities Journal of Localitology, Pusan National University, Korea and National Research Foundation of Korea (ISSN 2234-5663), Republic of Korea. Vol 7. 20I7, Pp, 3-4I, 
http://www.localities.kr/bbs/board.php?_table=database\&wr_id=8. 2017

. Migration and Brain Drain on Africa's Development: Establishing the nexus and Lessons of History Paper prepared for presentation at the International Conference on The Humanities and Development in Africa organised by Department of History, University of Ibadan, Ibadan Nigeria; 6-9July, 20I7, Conference Centre, University of Ibadan, Nigeria. 2017

Asenime, J, Women Trafficking in Nigeria up to 2008AD, SAU Journal of Humanities, Samuel Adegboyega University, Vol. I, No. I, September. 2012

Ayandele, E, Nigerian Historical Studies, Frank Cass and Company, London, p, 8. 2012

Ayoade, J. O. Climate Change. Ibadan. Vantage Publishers, pp. 45-66. 2004 Ayuba, H. et al. Climate change impact on plant species composition in six semi-arid rangelands of Northern Nigeria. Nigerian Geographical Journal 5(I): 35-42. 2007

Azad, Sher (22 October 20II). "Gaddafi and the media". Daily News. Archived from the original on 26 October 20I2. Retrieved 22 October 2OII

Babagana, Abubakar. The Impacts of Global Climate Change in Africa: the Lake Chad, Adaptation and Vulnerability, Fezzan Ward, Fezzan, Maiduguri, Borno State, Nigeria. 2017

. Water Availability, Supply and its Associated Problems in Rural Communities of Borno State. A. Case Study of Nganzai Local Government Area of Borno State, Nigeria IO-I9. (Unpublished). 2007

Barkindo, Bawuro. "The early states of the Central Sudan”, in: J. Ajayi and M. Crowder (eds.), The History of West Africa, vol. I, 3rd ed. Harlow, 225-254. 1985

Bart, Heinrich (1858). "Chronological table, containing a list of the Sefuwa", in: Travel and Discoveries in North and Central Africa. Vol. II, New York, 58I-602. 2018

Bearman, Jonathan. Qadhafi's Libya. London: Zed Books. I986

Burns, Alan. History of Nigeria. London George Allen and Unwin. I929

Chindo, Nyelong P. A. Lake Chad: From Megalake to Minilake. Arid Wetland Bulletin No. 6:24-27. 2004 
Connah, G. Some Contributions of Archaeology to the study of the History of Borno, in Usman Y.B and Alkali N (1983) (edt), Studies in the History of Pre Colonial Borno. Northern Nigeria Publishing Company, Zaria. I983

Dayo, Oketola; Adepegba, Adelani; Kunle, Falayi and Alexander, Okere (20I7) Fellow Nigerians abducted, sold us into Slavery in Libya; Punch, December 2.

Elbagir, Nima; Leposo, Lilian; John, Hassan (20I8): CNN Exclusive Report: Don't Struggle if you're Raped; http:www.cnn.com/2018/02/27/Africa/Nigeria-migrant-smugglers.intl/index.html

El-Mahdi, M. A short History of the Sudan, Oxford O.U.P. I965

Fage, J.D. "Some Thoughts on State Formation in Western Sudan Before the Seventeenth Century" in J. Butler (ed.) Boston University papers in African History, Vol. I Boston, Boston University. I964

Fuglestad, F. "A Reconsideration of Hausa history before the jihad J.A.H XIX, 3, pp 319-339. I978

Greenberg, J. H. Studies in African Linguistic Classification, New Haven. I955

. "Influence of Meroi Empire on Kordofan" in J. Butler, (ed.) Boston University Papers in African History. Vol. I, Boston University Press. 1964

Hodgkins, Thomas (i960), The Nigerian Perspectives. Oxford University Press London; p.26I

Hopkins, A. G. An Economic Hisotry of West Africa, London Longman. I973

Horton, R. "Stateless Societies in the History of West Africa in Ajayi and Crowder (eds.)

History of West Africa Vol. I 2nd ed. London Longman pp. 72- II3. 1976

Jagtap, S. Managing vulnerability to extreme weather and climate events: Implications for agriculture and food security in Africa. Proceedings of the International Conference on Climate Change and Economic Sustainability held at Nnamdi Azikiwe University, Enugu, Nigeria. I2-I4 June 2007.

Jogan, Carling. Trafficking in Women from Nigeria to Europe. International Research Institute, Oslo (PRIO), http://www.migrationinformation.org/feature/display.cfm? Id=318,2005 
Kenny, J. The Spread of Islam Through North to West Africa 7th to I9th Centuries: A Historical Survey with Relevant Arab Documents, Domminican Publications, Lagos;

. The Spread of Islam Through North to West Africa 7 th to Igth Centuries: ...Op.cit. 30

Kingsley, Omonobi "Gaddafi wanted to break Nigeria”, Vanguard , 22 October, 2OII

Kwanashie, George et al. "A Little New Light: Selected Historical Writings of Professor Abdullahi Smith" Vol. I. Centre for Historical Research, Zaria, Nigeria. 1987

Last, M.D The Sokoto Caliphate London, Longman, I977

. "The kingdoms and peoples of Chad", in: D. T. Niane (ed.), General History of Africa, vol. IV, UNESCO, London I984, 238-265. I984 . The Founding of Kanem by Assyrian Refugees ca. 600 BCE: Documentary, Linguistic, and Archaeological Evidence, Boston, Working Papers in African Studies $\mathrm{N}^{\circ}$ 265. $201 \mathrm{II}$

Lavers, John. "Adventures in the chronology of the states of the Chad Basin". In: D. Barreteau and C. v. Graffenried (eds.), Datations et chronologies dans le Bassin du Lac Chad, Paris, 255-267. I993

Levtzion, Nehemia. "The Saharan and the Sudan from the Arab conquest of the Maghrib to the rise of the Almoravids", in: J. D. Fage (ed.), The Cambridge History of Africa, vol. II, Cambridge I978, pp. 637684. 1978

Levtzion, Nehemia und John Hopkins: Corpus of Early Arabic Sources for West African History. I98I

McLachlan, K.S. Tripoli and Tripolitania: Conflict and Cohesion during the Period of the Barbary Corsairs (I55I-I85O). Translations of the Institute of British Geographers, New Series, Vol, 3, No 3, Settlement and Conflict in the Mediterranean World, Pp285-294. Lisa Anderson (I984), Nineteenth Century Reform in Ottoman Libya, International Journal of Middle East Studies, Vol. I6, No. 3, August I984, pp. 325-348, Slavery In Libya. I984

Mathew, Womack Ryan "The Emergence of Neoliberalism and Free Trade in the Developing World" (2006), University of Tennessee Honors Thesis Projects. https://trace.tennessee.edu/utk_chanhonopio/IO30

Mshelia, A. D. Adaptation strategies to climate change. Journal of Energy and Environment, I8 (3): 74-8I. 2005 
Muhammad-Baba, T. A. Pastoral Fulbe Transhumance in the context of the Nigeria-Niger Border: Implications for Trans-National Co-operation in Asiwaju A.I and Barkindo, B.M(ed), The Nigeria-Niger Transborder Co-operation. Malthouse Press Ltd. Lagos. I992

Na-Dama, Garba. "The Rise and Collapse of Hausaland States: A Social and Political History of Zamfara”. Ph.D Thesis A.B.U. I977

Nigeria. Trafficking in Persons Report 20IO. U.S. Department of State (June I4, 20I0); see also Curbing International Prostitution in Edo, ThisDay, 3I Aug 20I4; Read more: http://www.onlinenigeria.com/aids/ edo_prosti.asp\#ixzz3RWdXlGXH. 20I4

Nigerian Environmental Study/Action Team (NEST) 2003. Climate Change in Nigeria. A Communication Guide for Reporters and Educators. Ibadan: NEST pp. 5-16. 2003

Nwafor, J. C. Environmental Impact Assessment for Sustainable Development: The Nigerian perspective. Enugu: EL 'DEMAK pubs, pp. 359394. 2006

Odjugo, P. A. O.; IKHUORIA, A. I. The impact of climate change and anthropogenic factors on desertification in the semi-arid region of Nigeria. Global Journal of Environmental Science, 2(2): II8-I26. 2003

Osalors, Peter. Nigerian Economic Recession and Entrepreneurial Revolution On September 26, 2016r:56 amIn Finance Comments, vanguardngr.com/2016/09. 2016

Paiidam-20i6 (Pan Africa Initiative Against Irregular And Dangerous Migration). 2016

Shimatsu, Yoichi. "Villain or Hero? Desert Lion Perishes, Leaving West Explosive Legacy". New America Media. Retrieved 23 October 20II

Smith, Abdullahi. The early states of the Central Sudan, in: J. Ajayi and M. Crowder (Hg.), History of West Africa. Vol. I, I. Aug., London, I58I83. I97I

Stewart, John. African States and Rulers: An encyclopedia of Native, Colonial and Independent States and Rulers Past and Present. Jefferson, NC: McFarland \& Company, Inc. Publishers. I989

UCDP Database-2oiı (Uppsala Conflict Data Program). Uppsala, Department of Peace and Conflict Research, Uppsala University. 20II

UNESCO, Research Study on "Human Trafficking especially of Women and Children in West Africa (Benin, Togo, Nigeria)” 2006 
Usman, Mohammed. International Political Economy Of Nigerian Amalgamation Since I9I4. European Scientific Journal October 2013 edition vol.9, No.29 ISSN: I857 - 788I (Print) e - ISSN I857-743I429, Pp 7-8. 2013

Usman, Y. B. "The Transformation of Katsina: The Overthrow of the Sarauta system and the Establishement of the Emirate, C. I796-I903, Ph.D. Thesis, A.B.U. I974

. A Reconsideration of the History of Relationships Between Borno and

Hausa-Land, in Usman Y.B and Alkali N (1983) (edt), Studies in the History of Pre Colonial Borno. Northern Nigeria Publishing Company, Zaria. I983

Yaro, Joseph A, (nd), Migration in West Africa: Patterns, Issues and Challenges, Centre for Migration Studies, University of Ghana, Legon. 2008

Zimbabwe: Reason Wafavarova - Reverence for Hatred of Democracy". Al1Africa.com. 2I July 20II. Retrieved 23 October 201 I.

\begin{abstract}
The Economic situation in most Third World countries since independence have not shown signs of improvement. The result is that those at the prime of their lives which would have stirred the economy to greater height are moving en masse out of the area in search of greener pastures elsewhere especially across the desert into Europe, a situation that has negatively affected her development over the years in these Third World Countries using Nigeria as example. The impact-effect as well as the how, why and when of this is what this paper intends to interrogate as it relates to the Nigerian situation as well as those of her neighbours especially in the last two centuries using the facts and lessons of history. Data obtained from primary and secondary sources (literature review and content analysis) were deployed to carry out the study with an analytical and narrative historical method.
\end{abstract}

\title{
KEYWORDS
}

Economy; Third World; Greener Pastures; Desert. 